\title{
KUALITAS PERAIRAN SUNGAI BREMI KABUPATEN PEKALONGAN DITINJAU DARI FAKTOR FISIKA-KIMIA SEDIMEN DAN KELIMPAHAN HEWAN MAKROBENTOS
}

\author{
Tiara Esha Kinanti, Siti Rudiyanti ${ }^{1}$, Frida Purwanti
}

Program Studi Manajemen Sumberdaya Perairan, Jurusan Perikanan Fakultas Perikanan dan Ilmu Kelautan, Universitas Diponegoro

\begin{abstract}
ABSTRAK
Sungai Bremi merupakan salah satu sungai di Kabupaten Pekalongan yang sudah mengalami penurunan kualitas dilihat dari warna airnya yang hitam keruh dan berbau tak sedap. Penurunan kualitas Sungai Bremi diantaranya disebabkan oleh berbagai masukan limbah dari aktivitas masyarakat dapat mempengaruhi kehidupan hewan makrobentos. Penelitian ini bertujuan untuk mengetahui tekstur sedimen dan kandungan bahan organik total yang terdapat dalam sedimen sungai, kelimpahan hewan makrobentos, hubungan antara tekstur sedimen, kandungan bahan organik total, dan kelimpahan hewan makrobentos, dan kualitas perairan di Sungai Bremi Kabupaten Pekalongan. Materi yang digunakan dalam penelitian ini adalah sedimen dasar perairan dan sampel hewan makrobentos yang diambil dari Sungai Bremi Kabupaten Pekalongan. Metode yang digunakan adalah metode survei dengan teknik pengambilan sampel purpossive sampling yang dilakukan di tiga stasiun yang berbeda. Pengukuran parameter kualitas air meliputi suhu, oksigen terlarut, $\mathrm{pH}$, kecepatan arus, kedalaman dan kecerahan.

Hasil penelitian menunjukkan tekstur sedimen adalah lanau berpasir dan kandungan bahan organik total termasuk dalam kategori sedang-tinggi dengan nilai antara $16,89 \%-21,58 \%$. Kelimpahan hewan makrobentos pada stasiun I sebesar $1264 \mathrm{ind} / \mathrm{m}^{3}$ terdiri dari Tubifex sp., Nereis sp., Chironomus sp., dan Lymnaea sp., sedangkan pada stasiun II dan III tidak ditemukan hewan makrobentos. Hubungan antara kandungan bahan organik total sedimen dengan tekstur sedimen dari uji regresi linier menunjukkan nilai $r$ sebesar 0,955 sedangkan hubungan antara kandungan bahan organik total sedimen dan tekstur sedimen dengan kelimpahan hewan makrobentos dari uji regresi linier berganda mempunyai nilai $r$ sebesar 1 yang artinya kelimpahan hewan makrobentos memiliki hubungan yang sangat kuat dengan kandungan bahan organik total dan tekstur sedimen. Kualitas perairan Sungai Bremi berdasarkan indeks keanekaragaman hewan makrobentos termasuk pada kategori tercemar berat dengan indeks keanekaragaman sebesar 0,626.
\end{abstract}

Kata kunci : Bahan Organik Total, Tekstur Sedimen, Kelimpahan Makrobentos, Sungai Bremi

\section{ABSTRACT}

The Bremi River is one of rivers in the Pekalongan Regency in which its water quality has been degraded. It can be seen by the colour of the water which is black and have bad smell. The degraded water quality in Bremi River are caused by many sewages from people's activities that could affect macrobentos organisms. The aim of this research are knowing the sediment texture and total organic material contents in the sediment, abundance of macrobentos, relation between sediment texture, total organic material contents, and abundance of macrobentos, and the water quality in Bremi River Pekalongan Regency. The materials in this research were bottom sediment and macrobentos samples which collected from the Bremi River Pekalongan. The methods used in this research are survey methods with purpossive sampling technique in three different stations. Water quality parameters measurement consist of temperature, dissolved oxygen, $\mathrm{pH}$, current, depth and transparency.

The results shows the contents of total organic materials categorize in medium to high with value between 16,89\%-21,58\% and sediment texture of Bremi River is sandy silt. The abundance of macrobentos in station I is $1264 \mathrm{ind} / \mathrm{m}^{3}$ consist of Tubifex sp., Nereis sp., Chironomus sp., and Lymnaea sp., whereas in station II and III there was no macrobentos found. The relation between total organic materials with the sediment texture based on linier regression analysis shows $r$-value 0,955 and the relation between total organic material contents and the sediment texture with the abundance of macrobentos based on multiple regression analysis r-value 1 which shows a very strong correlation. The water quality in the Bremi River based on the diversity index of macrobentos is high polluted with the diversity index (H') in Bremi River 0,626.

Keywords: Total Organic Material, Sediment Texture, the Abundance of Macrobentos, Bremi River 


\section{Pendahuluan}

Sungai merupakan salah satu ekosistem air tawar yang sangat penting bagi kehidupan organisme. Beraneka ragam organisme hidup di sungai, mereka menjadikan sungai sebagai habitat, nursery ground, feeding ground, dan spawning ground. Tidak hanya organisme perairan saja yang bergantung terhadap sungai, manusia pun juga membutuhkan sungai. Jaman dahulu, air sungai banyak digunakan manusia untuk kegiatan sehari-hari seperti memasak, minum, mencuci, mandi, dan kegiatan lainnya, namun, seiring bertambah majunya dunia, kualitas sungai sudah tidak sebaik dulu. Salah satu sungai yang sudah mengalami penurunan kualitas adalah Sungai Bremi yang terletak di Pekalongan. Penurunan kualitas Sungai Bremi dapat dilihat dari warna airnya yang hitam keruh dan memiliki bau tak sedap. Sungai Bremi mengalami penurunan kualitas akibat masukan limbah dari berbagai macam sumber.

Aktivitas masyarakat di sekitar aliran sungai memegang andil dalam penurunan kualitas perairan Sungai Bremi. Bahan organik yang berasal dari aktivitas masyarakat yang terakumulasi dalam perairan dapat meningkatkan kesuburan perairan tersebut, namun apabila jumlahnya melebihi batas, maka dapat menyebabkan ledakan populasi suatu organisme.

Limbah organik merupakan sisa atau buangan dari berbagai aktivitas manusia seperti rumah tangga, industri, permukiman, peternakan, pertanian dan perikanan yang berupa bahan organik, yang biasanya tersusun oleh karbon, hidrogen, oksigen, nitrogen, fosfor, sulfur dan mineral lainnya. Limbah organik yang masuk ke dalam perairan dalam bentuk padatan akan langsung mengendap menuju dasar perairan, sedang bentuk lainnya berada di badan air (Garno, 2004 dan Porpraset, 1989 dalam Marganof, 2007).

Bahan organik memiliki kaitan dengan tekstur sedimen. Ardi (2002) dalam Amin et al, (2012) menyatakan bahwa sedimen berpasir memiliki kandungan bahan organik lebih sedikit dibandingkan sedimen lumpur, karena dasar perairan berlumpur cenderung mengakumulasi bahan organik yang terbawa oleh aliran air, dimana tekstur dan ukuran partikel yang halus memudahkan terserapnya bahan organik.

Ukuran butir sedimen mempengaruhi berapa jumlah kandungan bahan organik yang terdapat dalam sedimen. Semakin halus sedimen, semakin banyak pula jumlah bahan organik yang terdapat di dalamnya, begitupula sebaliknya. Banyaknya bahan organik yang terakumulasi dalam sedimen juga akan mempengaruhi kehidupan organisme, seperti hewan makrobentos yang hidupnya di dasar perairan, di dalamnya. Kandungan bahan organik yang terakumulasi dalam substrat dalam jumlah tertentu dapat menjadi pencemar.

Kualitas perairan dapat dilihat dari kandungan bahan organik total. Bahan organik total dipengaruhi oleh berbagai macam faktor yang salah satunya adalah teksur sedimen. Berdasarkan uraian di atas, maka penulis tertarik untuk melakukan penelitian mengenai Kualitas Perairan Berdasarkan Kandungan Bahan Organik Total dan Tekstur Sedimen Sungai Bremi Kabupaten Pekalongan.

Tujuan penelitian ini adalah untuk mengetahui tekstur sedimen dan kandungan bahan organik total yang terdapat dalam sedimen sungai, mengetahui kelimpahan hewan makrobentos di Sungai Bremi, mengetahui hubungan antara tekstur sedimen, kandungan bahan organik total, dan kelimpahan hewan makrobentos, dan mengetahui kualitas perairan Sungai Bremi.

\section{Materi dan Metode Penelitian}

\section{A. Materi Penelitian}

Materi yang digunakan dalam penelitian ini adalah sedimen dasar dan sampel hewan makrobentos yang diambil dari Sungai Bremi Kabupaten Pekalongan. Alat dan bahan yang digunakan dalam penelitian ini adalah Ekman grab untuk mengambil sampel sedimen dan hewan makrobentos, saringan bentos untuk memisahkan antara hewan makrobentos dengan sedimen, formalin 4\% dan Rose bengale untuk mengawetkan sampel hewan makrobentos, water quality checker untuk mengukur $\mathrm{pH}$, DO, dan suhu air. Secchi disk untuk mengukur kedalaman dan kecerahan perairan, bola arus untuk mengukur kecepatan arus, stopwatch untuk menghitung waktu, buku identifikasi untuk mengidentifikasi hewan makrobentos. Ember sebagai wadah untuk mengkomposit sampel, dan GPS untuk mengetahui koordinat lokasi pengambilan sampel.

\section{B. Metode Penelitian}

Penelitian ini dilaksanakan pada bulan Mei-Juni 2013. Pengambilan sampel dilakukan di Sungai Bremi Kabupaten Pekalongan. Analisa kandungan bahan organik total sedimen dan tekstur sedimen dilakukan di Laboratorium Pakan Ternak Fakults Pertanian dan Peternakan dan Laboratorium Mekanika Tanah Fakultas Teknik Sipil Universitas Diponegoro Semarang. Metode yang digunakan dalam penelitian ini adalah metode survei. Metode survei merupakan metode penelitian yang dilakukan untuk memperoleh faktafakta dari gejala yang terdapat di lapangan dan mencari informasi yang faktual. Metode penelitian ini dilakukan pada sekumpulan obyek dan berasumsi bahwa obyek yang diteliti telah mewakili populasi yang diamati (Hasan, 2004).

Penentuan titik pengambilan sampel dilakukan dengan metode purposive sampling (pengambilan sampel berdasarkan tujuan). Sampel yang akan diambil berdasarkan atas pertimbangan sesuai dengan maksud dan tujuan penelitian (Sukandarrumidi, 2006). Pertimbangan penentuan titik pengambilan sampel 
dilakukan dengan melihat pencemaran yang terjadi di aliran sungai. Penentuan titik sampling dilihat dari kawasan yang diperkirakan tidak mengalami pencemaran berat, memiliki tingkat pencemaran berat dan daerah yang masih terkena dampak cemaran.

Pengambilan sampel dilakukan sebanyak dua kali dengan interval waktu pengambilan sampel selama tiga minggu. Pengambilan sampel dilakukan pada 3 stasiun. Setiap stasiun memiliki 3 titik sampling dan setiap titik sampling memiiki tiga sub titik yang kemudian dilakukan pengambilan sampel dengan cara komposit.

Stasiun I : merupakan kawasan yang diperkirakan tidak terlalu banyak menerima buangan limbah, yaitu di Desa Jenggot. Memiliki warna air coklat. Berjarak $4 \mathrm{~km}$ dengan stasiun II. Lebar sungai $7 \mathrm{~m}$.

Stasiun II : merupakan kawasan yang diperkirakan menerima masukan bahan pencemar lebih banyak, yaitu di Desa Pasir Sari.memiliki warna air hitam pekat. Sedimen hitam dan memiliki bau tak sedap. Berjarak $3 \mathrm{~km}$ dengan stasiun III. Lebar sungai $5 \mathrm{~m}$.

Stasiun III: merupakan kawasan yang masih terkena dampak limbah, yaitu di daerah hilir Sungai Bremi. Terdapat kawasan pertambakan dan tanaman mangrove. Berjarak $1 \mathrm{~km}$ dari muara. Lebar sungai $9 \mathrm{~m}$.

Pengambilan sampel sedimen dan hewan makrobentos menggunakan Ekman Grab dengan volume $20 \times 20 \times 20 \mathrm{~cm}$. Hewan makrobentos yang bercampur dengan substrat disaring dengan menggunakan saringan bentos dengan ukuran mata saringan $0,5 \mathrm{~mm}$. Sampel dimasukkan ke dalam botol sampel yang berisi larutan formalin 4\% dan diberi Rose bengale sebanyak $3-4$ tetes. Identifikasi hewan makrobentos dilakukan di Laboratorium Manajemen Sumberdaya Perairan Fakultas Perikanan dan Ilmu Kelautan Universitas Diponegoro. Hewan makrobentos diidentifikasi dengan menggunaan buku identifikasi menurut Brinkhurst (1971), Burch (1989), Bolton (2012), dan Fauchald (1977). Tekstur sedimen dilihat untuk megetahui persentase fraksi kerikil, pasir, lanau, dan lempung. Pengukuran kualitas perairan juga dilakukan di lapangan saat pengambilan sampel.

Kelimpahan hewan makrobentos dihitung berdasarkan jumlah individu per satuan volume (ind $/ \mathrm{m}^{3}$ ). Menentukan keanekaragaman jenis ( $\left.\mathrm{H}^{\prime}\right)$ hewan makrobentos digunakan persamaan Shannon-Wienner. Mengetahui nilai indeks keseragaman (E) dengan membandingkan indeks keanekaragaman dengan nilai maksimumnya. Indeks dominansi (C) digunakan untuk mengetahui ada tidaknya hewan makrobentos yang mendominasi dalam suatu wilayah. Hubungan antara kandungan bahan organik total dalam sedimen dengan tekstur sedimen dilakukan dengan analisis regresi linier sederhana. Hubungan antara kandungan bahan organik total dalam sedimen dan tekstur sedimen dengan kelimpahan hewan makrobentos dianalisis dengan menggunakan regresi linier berganda.

\section{Hasil dan Pembahasan}

\section{A. Gambaran umum lokasi penelitian}

Kabupaten Pekalongan merupakan salah satu dari 35 Kabupaten/Kota di Provinsi Jawa Tengah, yang berada di daerah Pantura bagian barat sepanjang pantai utara Laut Jawa memanjang ke selatan dengan Kota Kajen sebagai Ibu Kota pusat pemerintahan. Wilayah Kabupaten Pekalongan memiliki luas $+836,13$ $\mathrm{km}^{3}$. Secara geografis terletak diantara: $6^{0}-7^{0} 23^{\prime}$ Lintang Selatan dan antara $109^{0}-109^{\circ} 78^{\prime}$ Bujur Timur yang berbatasan dengan:

Sebelah Timur : Kota Pekalongan dan Kabupaten Batang

Sebelah Utara : Laut Jawa, Kota Pekalongan

Sebelah Selatan : Kabupaten Banjarnegara

Sebelah Barat : Kabupaten Pemalang

Menurut Rahmawati et al, (2008), Kabupaten Pekalongan memiliki beberapa sungai salah satunya adalah Sungai Bremi. Sungai Bremi merupakan salah satu anak sungai dari Sungai Sengkarang selain Sungai Meduri yang merupakan salah satu sungai yang terletak dalam wilayah Sungai Pemali-Juana. Sungai Bremi berasal dari saluran pembuang irigasi pada bagian hulu yang masuk dalam wilayah administratif Kabupaten Pekalongan. Alur sungai ini juga melintasi wilayah Kotamadya Pekalongan yang padat. Dibandingkan Sungai Sengkarang dan Sungai Meduri, Sungai Bremi memiliki tingkat pencemaran terberat. Hal tersebut dapat dilihat dari warna airnya yang berwarna hitam pekat dan baunya tak sedap. Beberapa sistem drainase Kota Pekalongan terhubung langsung dengan Sungai Bremi.

\section{B. Hasil}

\section{Hasil analisa kandungan bahan organik total}

Rata-rata kandungan bahan organik total yang diperoleh dari hasil penelitian di Sungai Bremi tersaji pada Tabel 1. 
Tabel 1. Rata-rata Kandungan Bahan Organik Total Sedimen

\begin{tabular}{|c|c|c|c|c|}
\hline \multirow{2}{*}{ Stasiun } & \multicolumn{2}{|c|}{ Bahan Organik (\%) } & \multirow{2}{*}{ Kategori } & \multirow{2}{*}{ Pustaka } \\
\hline & Kisaran & Rata-rata & & \\
\hline $\mathrm{I}$ & $15,08-17,62$ & 16,89 & Sedang $7-17 \%$ & Reynold, 1971 dalam \\
\hline II & $20,67-22,92$ & 21,58 & Tinggi $17-35 \%$ & Febrianto, 2012 \\
\hline III & $18,26-24,46$ & 20,53 & Tinggi $17-35 \%$ & \\
\hline
\end{tabular}

Hasil analisa tekstur sedimen

Persentase fraksi sedimen yang diperoleh dari hasil penelitian di Sungai Bremi tersaji pada Tabel 2.

Tabel 2. Persentase Fraksi Sedimen di Sungai Bremi

\begin{tabular}{cccccc}
\hline \multirow{3}{*}{ Stasiun } & \multicolumn{4}{c}{ Persentase Individual (\%) } & Kriteria \\
\cline { 2 - 5 } & $\begin{array}{c}\text { Kerikil } \\
\text { (gravel) }\end{array}$ & $\begin{array}{c}\text { Pasir } \\
(\text { sand })\end{array}$ & $\begin{array}{c}\text { Lanau } \\
(\text { silt })\end{array}$ & $\begin{array}{c}\text { Lempung } \\
\text { (loam) }\end{array}$ & \\
\hline I & 0,00 & 44,10 & 47,83 & 8,07 & Lanau berpasir \\
II & 2,00 & 35,60 & 56,97 & 5,43 & Lanau berpasir \\
III & 3,00 & 35,00 & 57,93 & 4,07 & Lanau berpasir \\
\hline
\end{tabular}

Hasil analisa variabel kualitas air

Berdasarkan penelitian yang dilakukan di Sungai Bremi diperoleh nilai rata-rata parameter kualitas air yang tersaji pada Tabel 3 .

Tabel 3. Nilai Rata-rata Parameter Kualitas Air

\begin{tabular}{lcccl}
\hline \multirow{2}{*}{ Parameter } & \multicolumn{3}{c}{ Stasiun } & \multicolumn{1}{c}{ Referensi } \\
\cline { 2 - 5 } \multicolumn{1}{c}{ I } & II & III & \\
\hline Suhu Air $\left({ }^{\circ} \mathrm{C}\right)$ & 26,83 & 30,72 & 30,43 & $25-31{ }^{\circ} \mathrm{C}$ (Wijayanti, 2007) \\
Kecepatan Arus $(\mathrm{m} / \mathrm{s})$ & 0,019 & 0,048 & 0,074 & Sangat lambat $<10 \mathrm{~cm} / \mathrm{s}$ (Andriana, 2008) \\
$\mathrm{pH}$ & 4,47 & 3,95 & 3,84 & $>5$ dan $<9$ (Hynes, 1978 dalam Suwarno, 2000) \\
DO (mg/l) & 2,45 & 1,93 & 2,03 & $>5 \mathrm{mg} / \mathrm{l}$ (Kristanto, 2004 dalam Suparjo, 2009) \\
Kedalaman (m) & 0,87 & 1,39 & 1,17 & - \\
Kecerahan $(\mathrm{cm})$ & 26,58 & 15,04 & 17,5 & $>0,45 \mathrm{~m}$ (Asmawi (1983) dalam Suparjo, 2009) \\
\hline
\end{tabular}

\section{Hasil kelimpahan hewan makrobentos}

Berdasarkan hasil identifikasi hewan makrobentos yang telah dilakukan, didapatkan data kelimpahan hewan makrobentos yang dapat dilihat dalam Tabel 4.

Tabel 4. Kelimpahan Individu dan Kelimpahan Relatif Hewan Makrobentos di Sungai Bremi Kabupaten Pekalongan

\begin{tabular}{|c|c|c|c|c|c|c|c|c|c|c|}
\hline \multirow{3}{*}{ No } & \multirow{3}{*}{ Biota } & \multicolumn{9}{|c|}{ Stasiun } \\
\hline & & \multicolumn{3}{|c|}{$\mathrm{I}$} & \multicolumn{3}{|c|}{ II } & \multicolumn{3}{|c|}{ III } \\
\hline & & $\begin{array}{c}1 \\
\text { (Ind) }\end{array}$ & $\begin{array}{c}2 \\
\text { (Ind) }\end{array}$ & $\begin{array}{l}\mathrm{KR} \\
(\%)\end{array}$ & $\begin{array}{c}1 \\
\text { (Ind) }\end{array}$ & $\begin{array}{c}2 \\
\text { (Ind) }\end{array}$ & $\begin{array}{l}\text { KR } \\
(\%)\end{array}$ & $\begin{array}{c}1 \\
\text { (Ind) }\end{array}$ & $\begin{array}{c}2 \\
\text { (Ind) }\end{array}$ & $\begin{array}{l}\mathrm{KR} \\
(\%)\end{array}$ \\
\hline 1. & Tubifex sp. & 68 & 74 & 10,44 & 0 & 0 & 0 & 0 & 0 & 0 \\
\hline 2. & Nereis sp. & 3 & 5 & 4.4 & 0 & 0 & 0 & 0 & 0 & 0 \\
\hline 3. & Chironomus sp. & 8 & 11 & 78.02 & 0 & 0 & 0 & 0 & 0 & 0 \\
\hline 4. & Lymnaea sp. & 6 & 7 & 7.14 & 0 & 0 & 0 & 0 & 0 & 0 \\
\hline & Jumlah & 85 & 97 & 100 & 0 & 0 & 0 & 0 & 0 & 0 \\
\hline & Total Ind. & & 182 & & & 0 & & & 0 & \\
\hline & $\mathrm{KI}\left(\mathrm{Ind} / \mathrm{m}^{3}\right)$ & & 1264 & & & 0 & & & 0 & \\
\hline
\end{tabular}

Keterangan

$\begin{array}{ll}\mathrm{KI} & \left.=\text { Kelimpahan Individu (ind } / \mathrm{m}^{3}\right) \\ \mathrm{KR} & =\text { Kelimpahan Relatif }(\%)\end{array}$

Makrobentos hanya terdapat pada stasiun I. Kelimpahan hewan makrobentos yang ditemukan di Stasiun I terdiri dari empat spesies yaitu Tubifex sp., Nereis sp., Chironomus sp., dan Lymnaea sp. Kelimpahan relatif tertinggi yaitu Tubifex sp. Sebesar 78,02\% dan yang terendah adalah Nereis sp. Sebesar 4,4\%. Kelimpahan individu pada stasiun I sebesar $1264 \mathrm{ind} / \mathrm{m}^{3}$.

\section{Hasil perhitungan indeks keanekaragaman, keseragaman, dan dominansi}

Berdasarkan penelitian yang telah dilakukan di ketiga stasiun di Sungai Bremi Kabupaten Pekalongan diperoleh nilai Indeks Keanekaragaman, Indeks Keseragaman, dan Indeks Dominansi yang terdapat pada Tabel 5. 
Tabel 5. Nilai Indeks Keanekaragaman, Indeks Keseragaman, dan Indeks Dominansi

\begin{tabular}{cccc}
\hline Stasiun & H' $^{\prime}$ & E & C \\
\hline I & 0,618 & 0,445 & 0,626 \\
II & - & - & - \\
III & - & - & - \\
\hline
\end{tabular}

\section{Hasil Analisa regresi}

Hubungan antara kandungan bahan organik total dalam sedimen dengan tekstur sedimen dilakukan dengan uji regresi linier didapatkan nilai koefisien korelasi (r) sebesar 0,955 dan nilai koefisien determinasi $\left(\mathrm{R}^{2}\right)$ sebesar 0,912 dengan persamaan $\mathrm{Y}=0,412 \mathrm{X}-3,204$.

Hubungan antara kadungan bahan organik total dalam sedimen dan tekstur sedimen dengan kelimpahan hewan makrobentos dilakukan dengan uji linier berganda didapatkan nilai koefisien korelasi (r) dan koefisien determinasi $\left(R^{2}\right)$ sebesar 1 dengan persamaan $Y=-86,063 X_{1}-94,132 X_{2}+7219,926$.

\section{Pembahasan}

Berdasarkan kriteria kandungan bahan organik dalam sedimen menurut Reynold (1971) dalam Febrianto (2012), rata-rata kandungan bahan organik pada stasiun I sebesar 16,89 berada dalam kategori sedang. Rata-rata kandungan bahan organik pada stasiun II sebesar 21,58 berada pada kategori tinggi, begitu juga pada stasiun III, rata-rata kandungan bahan organiknya sebesar 20,53 dan masuk pada kategori bahan organik tinggi. Rata-rata kandungan bahan organik paling tinggi terdapat pada stasiun II. Hal tersebut diduga dikarenakan pada stasiun II mendapat masukan limbah paling banyak dari stasiun lainnya, merupakan perumahan padat penduduk dan pusat pembuangan limbah, terutama batik, sehingga masukan pencemar organik lebih tinggi.

Tidak ditemukannya hewan makrobentos di stasiun II dan III diduga disebabkan oleh kadar bahan organik yang tinggi. Menurut Roback (1974) dalam Siahaan et al, (2012) bahan organik yang tinggi akan menjadi faktor pembatas bagi kehidupan hewan makrobentos.

Ketiga stasiun memiliki tipe substrat lanau berpasir karena fraksi sedimen yang mendominasi adalah fraksi lanau dan disusul oleh fraksi pasir. Rata-rata kandungan fraksi lanau yang tinggi di ketiga stasiun turut menyumbang peranan dalam menyebabkan kandungan bahan organik tinggi. Hal tersebut karena substrat yang memiliki butiran halus lebih dapat mengakumulasi bahan organik. Menurut Sunarmi et al, (2006) dalam Usro et al, (2013), Sedimen dengan tekstur liat memiliki luas permukaan yang luas sehingga memiliki kemampuan yang tinggi dalam penyerapan unsur hara maupun menahan air, sehingga tanah yang memiliki tekstur halus akan lebih aktif dalam reaksi kimia dari pada tanah yang bertekstur kasar. Menurut Sanusi dan Putranto (2009) dalam Usro et al, (2013), tekstur dari sedimen dapat juga mempengaruhi jumlah bahan organik yang mengendap. Semakin halus tekstur dari sedimen perairan semakin banyak pengendapan bahan organik.

Partikel butir sedimen yang terdapat pada stasiun II dan III lebih halus daripada stasiun I, hal tersebut diduga merupakan salah satu faktor yang mempengaruhi kelimpahan hewan makrobentos yang ditemukan di Sungai Bremi. Menurut Pangastuti (1999), keadaan substrat lumpur yang mudah teraduk dan tersuspensi dapat menyebabkan alat pernafasan dan alat bantu penangkap makanan hewan makrobentos pemakan suspensi tertutup sehingga organisme akan tersingkir.

Partikel sedimen yang relatif halus yang mengendap di dasar Sungai Bremi disebabkan oleh arus yang lambat. Menurut Odum (1993) dalam Setiawan (2008), Pengendapan partikel lumpur di dasar perairan tergantung pada arus air jika arus air kuat, partikel yang mengendap berukuran besar dan jika arus air tidak kuat, partikel yang mengendap akan memiliki ukuran yang lebih kecil.

Rata-rata suhu air di lokasi penelitian berkisar antara $26,8-30,72{ }^{\circ} \mathrm{C}$. Suhu air di stasiun II dan III tergolong cukup tinggi namun masih baik bagi kehidupan hewan makrobentos. Menurut Wijayanti (2007), suhu yang baik bagi pertumbuhan hewan makrobentos berkisar antara $25-31^{\circ} \mathrm{C}$.

Derajat keasaman di Sungai Bremi tergolong rendah dan cenderung asam diduga merupakan salah satu penyebab rendah dan bahkan tidak ditemukannya hewan makrobentos. Menurut Setiyaningsih (2001), nilai $\mathrm{pH}$ menunjukkan tingkat keasaman lingkungan yang mempengaruhi metabolisme makrozoobentos, apabila $\mathrm{pH}$ terlalu ekstrim (terlalu rendah/asam maupun terlalu tinggi/basa) maka akan mengganggu kelancaran proses metabolisme dan akan terjadi seleksi alam terhadap komunitas hewan makrobentos yang dapat beradaptasi pada kondisi lingkungan seperti di atas.

Kecepatan arus pada stasiun I sebesar $0,019 \mathrm{~m} / \mathrm{s}$, pada stasiun II sebesar $0,048 \mathrm{~m} / \mathrm{s}$, pada stasiun III sebesar 0,074 m/s. Kecepatan arus di sungai Bremi berdasarkan hasil tersebut tergolong sangat lambat menurut Andriana (2008), yaitu arus perairan tergolong sangat lambat apabila kecepatannya kurang dari 10 $\mathrm{cm} /$ detik. 
Kecepatan arus yang sangat lambat di Sungai Bremi diduga disebabkan oleh angin dan jenis substrat pada Sungai Bremi. Menurut Nybakken (1992) dalam Andriana (2008), kecepatan arus dapat dipengaruhi oleh keberadaan angin dan substrat-substrat yang terdapat di dasar perairan. Substrat ini dapat berupa lumpur, pasir, atau batu.

Kadar DO yang rendah kemungkinan disebabkan oleh kandungan bahan organik yang tinggi. Menurut Wijaya dan Hariyati (2009), rendahnya DO kemungkinan dikarenakan oleh pembuangan limbah yang mengandung bahan organik. Sebagian besar oksigen terlarut digunakan bakteri aerob untuk mengoksidasi karbon dan nitrogen dalam bahan organik menjadi karbondioksida dan air. Connel dan Miller (1995) dalam Taqwa (2010), menambahkan bahwa secara ekologis, konsentrasi oksigen terlarut juga menurun dengan adanya penambahan bahan organik, karena bahan organik tersebut akan diuraikan oleh mikroorganisme yang mengkonsumsi oksigen yang tersedia.

Bahan organik yang tinggi memiliki andil terhadap rendahnya kandungan oksigen terlarut di Sungai Bremi. Kandungan oksigen terlarut pada stasiun II dan III lebih rendah karena kandungan bahan organiknya lebih tinggi dari stasiun I. Menurut Pariwono (1996) dalam Manengkey (2010), bahan organik merupakan pencemar yang paling umum dijumpai dan dampak yang ditimbulkannya tidak langsung. Masalah yang ditimbulkannya adalah menurunkan kandungan oksigen.

Kedalaman Sungai Bremi di stasiun I, II, dan III adalah 0,87 m, 1,39 m, dan 1,27 m. Kecerahan di stasiun I sebesar $26,58 \mathrm{~cm}$, pada stasiun II sebesar $15,04 \mathrm{~cm}$, dan pada stasiun III sebesar 17,5 cm. Berdasarkan data tersebut, Sungai Bremi dengan kedalaman tertinggi terdapat pada stasiun II dan kedalaman terendah terdapat pada stasiun I, sedangkan kecerahan tertinggi terdapat pada stasiun I dan terendah terdapat pada stasiun II. Kecerahan di Sungai Bremi termasuk dalam kategori rendah, sesuai dengan Asmawi (1983) dalam Suparjo (2009), bahwa kecerahan yang baik yaitu >0,45 m.

Kecerahan di Sungai Bremi termasuk rendah. Hal tersebut dapat dilihat dari warna airnya yang hitam keruh. Kekeruhan perairan mengurangi penetrasi cahaya matahari ke dalam sungai. Menurut Odum (1993) dalam Taqwa (2010), interaksi antara faktor kekeruhan perairan dengan kedalaman perairan akan mempengaruhi penetrasi cahaya yang masuk ke dalam perairan, sehingga berpengaruh langsung pada kecerahan, selanjutnya akan mempengaruhi kehidupan hewan makrobentos.

Spesies yang paling banyak ditemukan pada stasiun I adalah Tubifex dan Chironomus. Spesies tersebut merupakan penanda bahwa perairannya dalam kondisi tercemar berat. Dessy (2006) dalam Rosyadi et al, (2009) menyatakan bahwa Tubifex sp. merupakan indikator pencemaran berat, terutama pencemaran organik. Sastrawijaya (2009) menjelaskan bahwa indikator pencemaran berat pada perairan ditandai dengan adanya organisme makrozoobentos jenis Nais, Chironomus, Tubifex, dan Eristalis.

Jumlah Nereis sp. Yang ditemukan pada stasiun I paling rendah, hal tersebut dikarenakan hanya sedikit spesies yang dapat hidup di air tawar. Menurut Foster (1972), jumlah spesies polychaeta air tawar di dunia sangat sedikit dibandingkan dengan jumlah spesies yang hidup di laut. Terdapat 60 famili polychaeta, namun hanya tujuh famili yang baru dapat dilaporkan dapat hidup di air tawar, diantaranya adalah Nereidae, Nephthyidae, Lumbrineridae, Spionidae, Capitellidae, Ampharetidae, Sabellidae and Serpulidae. Nereidae, dengan jumlah spesies air tawar terbanyak, dikenal akan kemampuan mereka dapat bertahan terhadap perubahan salinitas yang ekstrim dan sering dijadikan hewan percobaan untuk menguji ketahanan terhadap salinitas.

Rendahnya komposisi struktur hewan makrobentos di area studi menunjukkan telah terjadinya sesuatu terhadap ekosistem sehingga menyebabkan tekanan terhadap lingkungan. Organisme bentik sangat sensitif terhadap gangguan habitat, termasuk melimpahnya kandungan bahan organik dan terkontaminasinya sedimen oleh bahan beracun seperti halnya logam berat. Jenis organisme sangat bervariasi dalam responnya terhadap bahan pencemar, komunitas bentos akan mengalami perubahan secara dramatis dalam komposisi spesies dan kelimpahannya akibat pengaruh tekanan lingkungan dari bahan pencemar. Tekanan bahan pencemar yang akut seringkali mengakibatkan kematian dan spesies yang sangat sensitif secara mudah akan hilang dari komunitas (Bilyard, 1987; Daeur, 1987 dalam Sudaryanto, 2001).

Hasil penelitian yang telah dilakukan di Sungai Bremi, dapat diketahui nilai indeks keanekaragaman di stasiun I yaitu 0,618. Artinya bahwa keragaman jenisnya rendah. Menurut Odum (1971) dalam Fajriansyah (2011), bahwa jika indeks keanekaragaman jenis $\left(\mathrm{H}^{\prime}\right)<1$ berarti menunjukkan bahwa keanekaragaman jenisnya rendah.

Nilai keanekaragaman yang terdapat pada stasiun I yaitu sebesar 0,618 termasuk dalam kategori yang rendah yaitu menandakan bahwa perairan Sungai Bremi pada stasiun I sudah tercemar berat, seperti dikutip dari Lee et al, (1978) dalam Fachrul (2006) bahwa indeks keanekaragaman < 1,0 artinya perairan tersebut dalam keadaan tercemar berat.

Nilai indeks keseragaman (E) pada stasiun I sebesar 0,445. Nilai tersebut menunjukkan bahwa pada stasiun I keseragaman spesiesnya sedang. Menurut Setiyaningsih (2001), apabila didapatkan nilai indeks keseragaman lebih dari atau sama dengan 0,4 dan kurang dari $0,6(0,4 \leq \mathrm{E}<0,6)$, maka keseragaman spesiesnya termasuk dalam kategori keseragaman sedang. 
Indeks Dominansi pada stasiun I adalah sebesar 0,626. Nilai tersebut menunjukan bahwa ada spesies yang mendominasi. Dominansi dari suatu spesies ini dapat disebabkan oleh beberapa faktor, seperti yang disampaikan Odum (1996) dalam Setiyaningsih (2001), kategori Indeks Dominansi > 0 artinya terdapat spesies yang mendominasi di suatu perairan. Fajriansyah et al, (2011), juga menyatakan bahwa perhitungan nilai indeks dominansi (C) dilakukan untuk melihat ada tidaknya organisme makrozoobentos yang mendominasi dalam suatu ekosistem. Hal ini berkaitan erat dengan daya tahan tubuh dan adanya persaingan antara jenis yang satu dengan jenis yang lain.

Menurut Wilhm (1975) dalam Setiawan (2008), pada kondisi perairan tercemar berat hampir seluruh komunitas hewan makrobentos hilang kecuali cacing oligochaeta dan kelompok yang bernafas ke udara. Seluruh kehidupan mungkin saja hilang. Berdasarkan hal tersebut, tidak ditemukan hewan makrobentos pada stasiun II dan III mungkin saja menandakan bahwa perairan di stasiun tersebut dalam keadaan tercemar berat.

Hasil uji regresi linear antara tekstur sedimen dengan kandungan bahan organik total dalam sedimen menunjukkan nilai koefisien korelasi (r) sebesar 0,955 yang menurut Hasan (2003) menunjukkan hubungan yang kuat sekali antar variabel. Nilai koefisien determinasi $\left(R^{2}\right)$ sebesar 0,912 menunjukkan bahwa tekstur sedimen mempengaruhi kandungan bahan organik yang ada dalam sedimen sebesar $91,2 \%$. Hasil uji regresi linear berganda antara tekstur sedimen dan kandungan bahan organik dalam sedimen dengan kelimpahan hewan makrobentos didapatkan nilai koefisien korelasi (r) yaitu sebesar 1 yang menurut Hasan (2003) menunjukkan korelasi yang sempurna antar variabel-variabelnya. Nilai koefisien determinasi $\left(\mathrm{R}^{2}\right)$ menunjukan nilai 1 yang artinya bahwa tekstur sedimen dan kandungan bahan organik dalam sedimen $100 \%$ mempengaruhi kelimpahan hewan makrobentos yang ada di perairan.

\section{Kesimpulan}

Kesimpulan yang didapat dari penelitian ini antara lain :

1. Kandungan bahan organik total dalam sedimen di Sungai Bremi berada dalam kategori sedang hingga tinggi. Kandungan bahan organik sedang terdapat pada stasiun I yaitu sebesar 16,89\%. Kandungan bahan organik tinggi terdapat pada stasiun II dan III yaitu sebesar $21,58 \%$ dan 20,53 \%. Tekstur sedimen di Sungai Bremi adalah lanau berpasir

2. Kelimpahan spesies yang ada di Sungai Bremi terdiri dari Tubifex sp., Nereis sp., Chironomus sp., dan Lymnaea sp. Kelimpahan individu terdapat pada stasiun I yaitu $1264 \mathrm{ind} / \mathrm{m}^{3}$, sedangkan pada stasiun II dan III tidak ditemukan hewan makrobentos.

3. Berdasarkan nilai uji regresi linier antara kandungan bahan organik total sedimen dengan tekstur sedimen menunjukkan nilai 0,955 dan regresi linier berganda antara kandungan bahan organik total sedimen dan tekstur sedimen dengan kelimpahan hewan makrobentos dimana nilai $r$ adalah 1 , maka dapat disimpulkan bahwa kelimpahan hewan makrobenthos memiliki hubungan yang sangat kuat dengan kandungan bahan organik dalam sedimen dan tekstur sedimen; dan

4. Kualitas perairan Sungai Bremi pada stasiun I memiliki indeks keanekaragaman sebesar 0,626 termasuk pada kategori tercemar berat, sedangkan pada stasiun II dan III tidak terdapat kelimpahan individu hewan makrobentos.

\section{Ucapan Terima Kasih}

Ucapan terima kasih ditujukan kepada kepada Ir. Siti Rudiyanti, M.Si dan Dr. Ir. Frida Purwanti, M.Sc atas bimbingannya dalam penyusunan jurnal penelitian ini.

\section{DAFTAR PUSTAKA}

Amin, B., I. Nurrachmi, dan Marwan. 2012. Kandungan Bahan Organik Sedimen dan Kelimpahan Makrozoobentos Sebagai Indikator Pencemaran Perairan Pantai Tanjung Uban Kepulauan Riau. Universitas Riau. Pekanbaru.

Andriana, W. 2008. Keterkaitan Struktur Komunitas Makrozoobenthos Sebagai Indikator Keberadaan Bahan Organik di Perairan Hulu Sungai Cisadane Bogor, Jawa Barat [Skripsi]. Institut Pertanian Bogor. Bogor. 94 hal.

Bolton, M. J. 2012. Ohio EPA Suplemental Keys to the Larvar Chironomidae (Diptera) of Ohio and Ohio Chironomid Checklist. Environmental Protection Agency. Ohio. 111 p.

Brinkhurst, R. O. 1971. A Guide for the Identification of British Aquatic Oligochaeta. Freshwater Biological Assosiation Scientific Publication Volume 22. University of Toronto. Toronto. $58 \mathrm{p}$.

Burch, J. B. 1989. North American Freshwater Snails. The University of Michigan. United States of America. $186 \mathrm{p}$.

Fachrul, M. F. 2006. Metode Sampling Bioekologi. Bumi Aksara. Jakarta. 198 hal.

Fajriansyah, M. I., S. Nasution, dan J. Samiaji. 2011. Struktur Komunitas Makrozoobenthos di Perairan Desa Dompas Kecamatan Bukit Batu Kabupaten Bengkalis. Universitas Riau. Pekanbaru. 
Fauchald, K. 1977. The Polychaete Worms Definitions and Keys to the Orders, Families and Genera. Natural History Museum of Los Angeles County in Conjunction with The Allan Hancock Foundation. University Of Southern California. $192 \mathrm{p}$.

Febrianto, H. 2012. Distribusi Spasial Kelimpahan Makrobenthos Di Daerah Supralitoral Berpasir Besi Pantai Balong Kecamatan Keling Kabupaten Jepara [Skripsi]. Universitas Diponegoro. Semarang.

Foster, N. 1972. Biota of Freshwater Ecosystem Identification Manual Number 4 Freshwater Polychaetes (Annelida) of North America. U.S. Goverment Printing Office. Washington D.C. 36 p.

Hasan, M. I. 2003. Pokok-pokok Materi Statistik 1 (Deskripsi Deskriptif). Edisi Kedua. Bumi Aksara: Jakarta . 2004. Analisis Data Penelitian Dengan Statistik. Bumi Aksara: Jakarta.

Marganof. 2007. Model Pengendalian Pencemaran Perairan di Danau Maninjau Sumatera Barat [Disertasi]. Institut Pertanian Bogor. Bogor. 181 hal.

Manengkey, H.W.K.. 2010. Kandungan Bahan Organik di Perairan Teluk Buyat dan Sekitarnya. Jurnal Perikanan dan Kelautan Tropis. 6 (3): 114 - 119.

Pangastuti, R. 1999. Kelimpahan dan Keanekaragaman Hewan Makrobentos pada Berbagai Tipe Substrat Perairan Pantai di Pulau Karimun Jawa [Skripsi]. Universitas Diponegoro, Semarang. 65 hal.

Rahmawati, I. Puspita dan A. Nunik. 2008. Sistem Pengendalian Banjir Sungai Sengkarang (Normalisasi Sungai) (Flood Control System Of Sengkarang River) [Tesis]. Universitas Diponegoro. Semarang.

Rosyadi, S. Nasution, dan Thamrin. 2009. Distribusi Dan Kelimpahan Makrozoobentos Di Sungai Singingi Riau. Journal of Environmental Science. 3 (1): 58 - 74.

Sastrawijaya, A. T. 2009. Pencemaran Lingkungan. Rineka Cipta: Jakarta.

Setiawan, D. 2008. Struktur Komunitas Makrozoobentos Sebagai Indikator Kualitas Lingkungan Perairan Hilir Sungai Musi [Tesis]. Institut Pertanian Bogor. Bogor. 193 hal.

Setiyaningsih, I. A. 2001. Struktur Komunitas Makrozoobenthos di Sedimen Dasar Sungai Cileungsi Bekasi, Kabupaten Bogor, Jawa Barat [Skripsi]. Institut Pertanian Bogor. Bogor. 65 hal.

Siahaan, R., A. Indrawan, D. Soedharma, dan L.B. Prasetyo. 2012. Keanekaragaman Makrozoobetos Sebagai Indikator Kualitas Air Sungai Cisadane, Jawa Barat-Banten. Jurnal Bioslogos. 2 (1): 1 - 9.

Sudaryanto, A. 2001. Struktur Komunitas Makrozoobenthos dan Kondisi Fisiko Kimiawi Sedimen di Perairan Donan, Cilacap-Jawa Tengah. Jurnal Teknologi Lingkungan. 2 (2): 119 - 123.

Sukandarrumidi. 2006. Metodologi Penelitian, Petunjuk Praktis untuk Peneliti Pemula. Gadjah Mada University Press. Yogyakarta.

Suparjo, M. N. 2009. Kondisi Pencemaran Perairan Sungai Babon Semarang. Jurnal Saintek Perikanan. 4 (2): $38-45$.

Suwarno, L. 2000. Struktur Komunitas Makrozoobenthos Sebagai Indikator Kualitas Lingkungan di Hulu Sungai Cimanuk, Garut, Jawa Barat [Skripsi]. Institut Pertanian Bogor. Bogor. 95 hal.

Taqwa, A. 2010. Analisis Produktivitas Primer Fitoplankton Dan Struktur Komunitas Fauna Makrobenthos Berdasarkan Kerapatan Mangrove Di Kawasan Konservasi Mangrove Dan Bekantan Kota Tarakan, Kalimantan Timur [Tesis]. Universitas Diponegoro. Semarang. 109 hal.

Usro, U. M., S. H. Julinda, dan Guntur. 2013. Konsentrasi Total Organic Carbon (TOC) pada Sedimen Permukaan di Perairan Muara Sungai Wonorejo Rungkut, Surabaya Timur. Iki Student Journal. 1 (1): $7-13$.

Wijaya, T. S. dan R. Hariyati. 2009. Struktur Komunitas Fitoplankton Sebagai Bio Indikator Kualitas Perairan Danau Rawa Pening Kabupaten Semarang Jawa Tengah. Universitas Diponegoro. Semarang.

Wijayanti, H. 2007. Kajian Kualitas Perairan di Pantai Kota Bandar Lampung Berdasarkan Komunitas Hewan Makrobentos [Tesis]. Universitas Diponegoro. Semarang. 89 hal. 